\title{
Study of maternal and fetal outcome in antepartum eclampsia in a tertiary care hospital
}

\section{Aruna Rani R., Dheeba Jayanthi R.*, Eswari S.}

Department of Obstetrics and Gynecology, Government Mohan Kumaramangalam Medical College, Salem, Tamil Nadu, India

Received: 10 January 2018

Accepted: 03 February 2018

\section{*Correspondence:}

Dr. Dheeba Jayanthi R.,

E-mail: rdheebajayanthi@gmail.com

Copyright: () the author(s), publisher and licensee Medip Academy. This is an open-access article distributed under the terms of the Creative Commons Attribution Non-Commercial License, which permits unrestricted non-commercial use, distribution, and reproduction in any medium, provided the original work is properly cited.

\section{ABSTRACT}

Background: In modern obstetrics, the prevalence of Eclampsia and its complications are high, so we decided to study pregnancy outcome in all Antepartum Eclampsia patients. The present study was carried out to investigate the maternal and fetal outcome in patient with Antepartum eclampsia.

Methods: A prospective study was conducted in Government Mohan Kumaramangalam Medical College Hospital, Salem, India over a period of one year from January 2016 to December 2016 in all Antepartum Eclampsia patients. Analysis was done regarding the age of women, parity, gestational age, imminent symptoms, mode of delivery, fetal outcome and maternal morbidity and mortality.

Results: Incidence of Antepartum Eclampsia in our hospital is $0.7 \%$. It is more common in age group of 20 to 25 years $(68.5 \%)$ and primigravida $(56 \%)$ and gestational age $>37$ weeks $(51.85 \%)$. Commonest mode of delivery was by caesarean section (72\%). Out of 54 patients of Antepartum Eclampsia $3(5.5 \%)$ died and $18(33 \%)$ had complications. Out of 50 live babies, $16(32 \%)$ died.

Conclusions: Eclampsia is still one of the important and common obstetric emergencies and it has a significant role in maternal and fetal outcome. The early identification of risk factors and timely intervention is needed to improve maternal and perinatal outcome.

Keywords: Eclampsia, Maternal complication, Primigravida, Perinatal outcome

\section{INTRODUCTION}

The term Eclampsia was derived from Greek word flash of lightening. It is one of the leading causes of maternal and perinatal morbidity as well as mortality throughout the world. ${ }^{1}$

Eclampsia is defined as the development of seizures that cannot be attributed to other causes and or unexplained coma during pregnancy or puerperium in a women with pre-eclampsia. $^{2}$ In developed countries, approximately 1 in 2000 deliveries is complicated by eclampsia, whereas the incidence in developing countries varies from 1 in
100 to 1 in 1700 cases. ${ }^{3}$ In India, its incidence is reported to be 220 per 10,000 deliveries. Maternal mortality is very high in india and varies from $2-30 \%$, much more in rural than in urban.

The perinatal mortality is very high of about $30-50 \% .^{5}$ Eclampsia is the third commonest cause of maternal mortality after haemorrhage and infection in the developing countries. ${ }^{6}$

It is estimated that about $7 \%$ of maternal mortality is associated with hypertensive disorders of pregnancy, particularly eclampsia. ${ }^{7}$ Some clinical cases of maternal 
deaths in eclampsia are due to cardiopulmonary failure, acute renal failure, cerebrovascular accident (CVA), HELLP Syndrome (Haemolysis, Elevated liver enzymes and low platelets) and premature separation of placenta. ${ }^{8}$

Poor fetal outcome is mostly attributed by iatrogenic prematurity, respiratory distress syndrome (RDS), intrauterine asphyxia, intrauterine growth restriction (IUGR) and intrauterine death (IUD). Additionally, at later stages of life, IUGR may result in neurodevelopmental defects in children. ${ }^{9}$

\section{METHODS}

This prospective study was conducted over a period of 1 year at Obstetrics and Gynaecology department of Government Mohan Kumaramangalam Medical College Hospital, Salem, Tamilnadu.

All Antepartum eclampsia patients who were admitted in causality from January 2016 to December 2016 were included in this study. These cases were evaluated by detailed history, thorough clinic examination, CT and blood investigations. Pregnancy was terminated in all patients irrespective of gestational age. All cases were treated with Magnesium sulphate (Pritchad regimen).

Hypertension was controlled with intravenous /oral labetolol and nifedipine if necessary. Only 54 patients who met the inclusion and exclusion criteria were included in this study. The variables analysed were age, parity, booking status, gestational age, imminent symptoms, blood pressure, and mode of delivery, fetomaternal morbidity and mortality.

\section{Inclusion criteria}

Patients with antepartum eclampsia.

\section{Exclusion criteria}

- Patient with convulsion due to causes other than eclampsia

- Intrapartum and postpartum eclampsia.

\section{RESULTS}

In present study 54 antepartum eclampsia patients were included. Table 1 shows that the maximum patients were in the age of 20 to 25 years $37(68.5 \%)$, only 3 cases were unbooked, primigravida comprised about 30 (56\%).

It was observed that 9 cases $(16.6 \%)$ presented at gestational age of $27-30$ weeks, 17 cases $(31.4 \%)$ in the gestational age of $31-36$ weeks while 28 cases $(51.85 \%)$ had gestational age of 37-40 weeks. CT scan was taken in 50 patients. CT scan finding was normal in 35 patients (64.8\%), PRES 11 (20.3\%), Haemorrhage 4 (7.4\%) and only one patient had multiple calcified lesions in cerebral lobes.
Table 1: Patient profile.

\begin{tabular}{|lll|}
\hline Age (years) & No. of patients & $\%$ \\
\hline$<20$ & 7 & 13 \\
\hline $20-25$ & 37 & 68.5 \\
\hline $26-30$ & 8 & 14.8 \\
\hline $31-40$ & 2 & 3.7 \\
\hline Parity & & \\
\hline Primi & 30 & 56 \\
\hline Multi & 24 & 44 \\
\hline GA (weeks) & & \\
\hline $24-30$ & 9 & 16.6 \\
\hline $31-36$ & 17 & 31.4 \\
\hline $37-40$ & 28 & 51.85 \\
\hline Booking Status & & \\
\hline Booked & 51 & 94.4 \\
\hline Unbooked & 3 & 5.6 \\
\hline PIH & & \\
\hline Known preeclampsia & 10 & 18.5 \\
\hline Not a known preeclampsia & 40 & 75.9 \\
\hline Recurrent preeclampsia & 3 & 5.5 \\
\hline CT & & \\
\hline Normal & 35 & 64.8 \\
\hline PRES & 11 & 7.4 \\
\hline Haemorrhage & 4 & 7.4 \\
\hline Not Taken & 4 & \\
\hline
\end{tabular}

Figure 1 shows that the main presenting complaint in the study group was headache $84 \%$ followed by headache with vomiting.

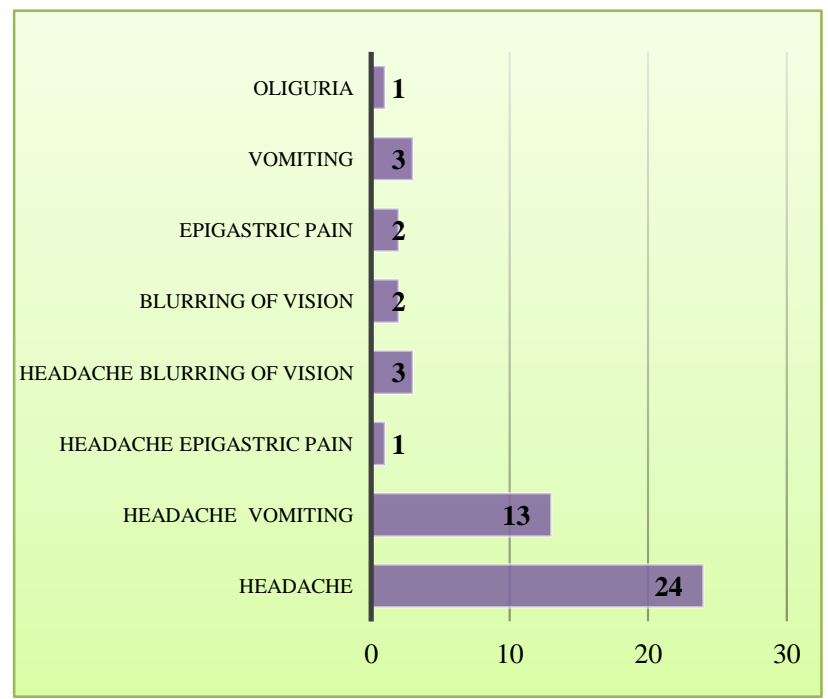

Figure 1: Symptoms in study group.

Table 2 shows that 39 cases were delivered by caesarean section $(72 \%)$ and the common indication was unfavourable cervix $-30(76 \%) .3$ out of 54 cases died. 18 patients developed complications like pulmonary edema $2(11 \%)$, CVA $4(22 \%)$, renal impairment 2 (11), abruptio placenta $3(16.6 \%)$, HELLP $3(16.6 \%)$, ARDS $1(5.5 \%)$ and DIVC $3(16.6 \%)$. With regard to fetal outcome, 50 $(92.5 \%)$ babies were alive and $4(7.4 \%)$ were dead born. 
Table 2: Fetal outcome.

\begin{tabular}{|lll|}
\hline Mode of delivery & No. of patients & $\%$ \\
\hline Labour natural & 9 & 17.0 \\
\hline Spontaneous expulsion & 3 & 5.5 \\
\hline LSCS & 39 & 72 \\
\hline Hysterotomy & 3 & 5.5 \\
\hline Fetal outcome & & \\
\hline Live birth & 50 & 92.9 \\
\hline Dead born & 4 & 7.4 \\
\hline Birth weight & & \\
\hline$<2.5 \mathrm{Kg}$ & 35 & 65 \\
\hline $2.6-3 \mathrm{~kg}$ & 13 & 24 \\
\hline$>3 \mathrm{Kg}$ & 6 & 11 \\
\hline Apgar score & & \\
\hline$<7$ & 13 & 26 \\
\hline$>7$ & 37 & 74 \\
\hline
\end{tabular}

Out of 50 babies, <2.5 Kg 35 (65\%), 2.6 to $3 \mathrm{Kg} 13$ (24\%), and $>3 \mathrm{Kg} 6(11 \%)$. Perinatal mortality rate was $37 \%$. Early neonatal death was 16 (32\%), due to prematurity and septicemia $6(37.5 \%)$, prematurity and RDS 6 (37.5\%), birth asphyxia $2(12.5 \%)$ and IUGR/meconium aspiration syndrome 2 (12.5\%).

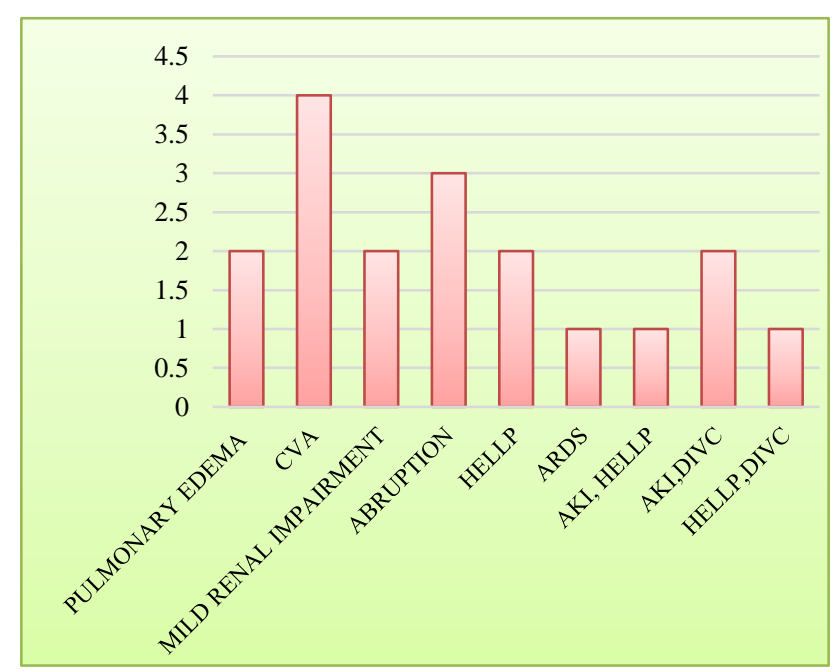

Figure 2: Maternal morbidity.

\section{DISCUSSION}

The incidence of eclampsia varies geographically according to the standard of antenatal care facilities provided in that area. In this study, the incidence $0.7 \%$, which is comparable to other developing countries with the incidence of 1 in 100 to 1 in 700 pregnancies. ${ }^{10-12}$

Eclampsia is more common in young primigravida. In the present study, eclampsia was more common in primigravida with age group of 20-25 years with 37 cases $(68.5 \%)$ while in less than 20 years of age there were 7 cases (13\%). In present study, highest numbers of eclamptic patient were found in the gestational age $\geq 37$ weeks 28 cases $(51.85 \%)$, followed by less than 37 weeks 17 cases $(31.4 \%)$, only 9 cases are found below 30 weeks of gestation. Similarly, Sunitha et al, Prabhakar et al and choudhary also found highest number of eclampsia patients in gestational age $\geq 37$ weeks.

The definitive treatment of eclampsia is delivery, irrespective of gestational age. Lower segment caesarean section was the commonest mode of delivery in present study $72 \%$. Similar observation was found in the study by Choudhary and Manjusha et al. ${ }^{13,14}$

Ante partum eclampsia is one of the leading cause of maternal mortality worldwide, it varies from $1.8-27.5 \%$. Maternal mortality in our study is $5.5 \%$. Almost one third of patient suffer from complications. ${ }^{15,16}$

CT brain was taken in all patients except 4. 35 patients had normal study, PRES in 11patients and 4 patients had cerebral haemorrhage.

In this study, acute kidney injury with DIVC was seen in 3 patients, 4 patients had cerebrovascular accident, 3 patients with abruptio placenta and 2 patients presented with pulmonary edema. In present study, out of 3 maternal deaths 2 patients died of acute kidney injury with DIVC and one patient died of HELLP with DIVC.

The percentage of live birth and still birth in our study was $92.5 \%$ and $7.4 \%$ respectively. Significant association has been noted between eclampsia and perinatal mortality and morbidity. Perinatal mortality was $20(37 \%)$ in current study, which was contributed by $4(7.4 \%)$ of still birth and $16(29.6 \%)$ of early neonatal death. Prematurity with septicaemia and respiratory distress syndrome was the major cause of neonatal death. Maternal morbidity and mortality were reduced because of early intervention whereas babies were exposed to the risk of prematurity.

\section{CONCLUSION}

This study reveals that eclampsia is still an important obstetric emergency in the community, as it contributes to significant maternal and perinatal morbidity and mortality. Good antenatal care, early identification of pre eclampsia and its complications, timely intervention can reduce the high incidence of eclampsia. As eclampsia is a preventable disease, early identification of high risk cases and early referral might reduce feto maternal morbidity and mortality.

\section{Funding: No funding sources \\ Conflict of interest: None declared}

Ethical approval: The study was approved by the Institutional Ethics Committee

\section{REFERENCES}

1. Tuffnell DJ, Jankowisz D, Lindow SW, Lyons G, Mason GC, Rusell LF et al. Outcomes of severe pre 
eclampsia/eclampsia in Yorkshire 1999 /2003 BJOG. 2005;112:875-80.

2. Singh BM, Mishra R. Hypertensive disorders. Mishra R, editor. Ian Donalds Obstetric Problem , Seventh edition, BI Publications Pvt Ltd: NewDelhi;2014:142-75.

3. Dukkit K, Harrington D. Risk factors for preeclampsia at antenatal booking: systemic review of controlled studies. BMJ. 2005 Mar;330(7491):565

4. Swain S, Ojha KN. Maternal and perinatal mortality due to eclampsia. Indian Pediatr. 1993;30(6):771-3.

5. Dutta DC. Hypertensive disorders in pregnancy. Konar H, editor. Text book of obstetrics, 7th edition, New Central Book Agency (P) Ltd: Kolkata;2011:219-40.

6. Mynemba J. Magnesium sulphate for eclampsia: putting evidence into clinical practice. Cent Afr J Med. 2000 Jun 46(6):166-9.

7. The WHO Application of ICD-10 to deaths during pregnancy, childbirth and the puerperium: ICD-MM. 2013:13. Available at http://apps.who.int/iris/bitstream/10665/70929/1/978 9241548458_eng.pdf

8. Onuh OS, Aisien OA. Maternal and fetal outcome in eclamptic patients in Benin City, Nigeria. J Obstet Gynaecol. 2004;24:765-8.

9. Ara J, Musarrat J, Sultana N. Perinatal outcome in pregnancy induced hypertension mothers. Pak Armed Forces Med J. 2004;54:76-8.
10. World Heath Organisation International. Collaborative Study of Hypertensive Disorders of pregnancy. Geographic variation in the incidence of hypertension in pregnancy. Am $\mathrm{J}$ Obstet Gynecol.1958:158:80-3.

11. Crowther CA. Eclampsia at Harare Maternity Hospital- An epidemiological study. S Afr Med J. 1985;68:927-9.

12. Bergstom S, Povey G, Songane F, Ching C. Seasonal incidence of eclampsia and its relationship to meteorological data in Mozambique. J Perinat Med. 1992;20:153-8.

13. Choudhary P. Eclampsia: A hospital based retrospective study. Kathmandu Univ Med J. 2003;1(4):237-41.

14. Manjusha S, Vandana N, Sneha M, Atmaram PP. Eclampsia: A retrospective study in a tertiary care centre. Indian J Pharm Pract. 2013;6(1):69-73.

15. Rahmani MTH, Kamal MTF. Clinico Pathological study of pre eclampsia. Biomedica. 2000;16:60-5.

16. Gilani S, Hussan L. Eclampsia a major cause of maternal mortality. J Postgrad Med Inst. 2002;16:97.

Cite this article as: Rani AR, Jayanthi DR, Eswari S. Study of maternal and fetal outcome in antepartum eclampsia in a tertiary care hospital. Int J Reprod Contracept Obstet Gynecol 2018;7:1108-11. 